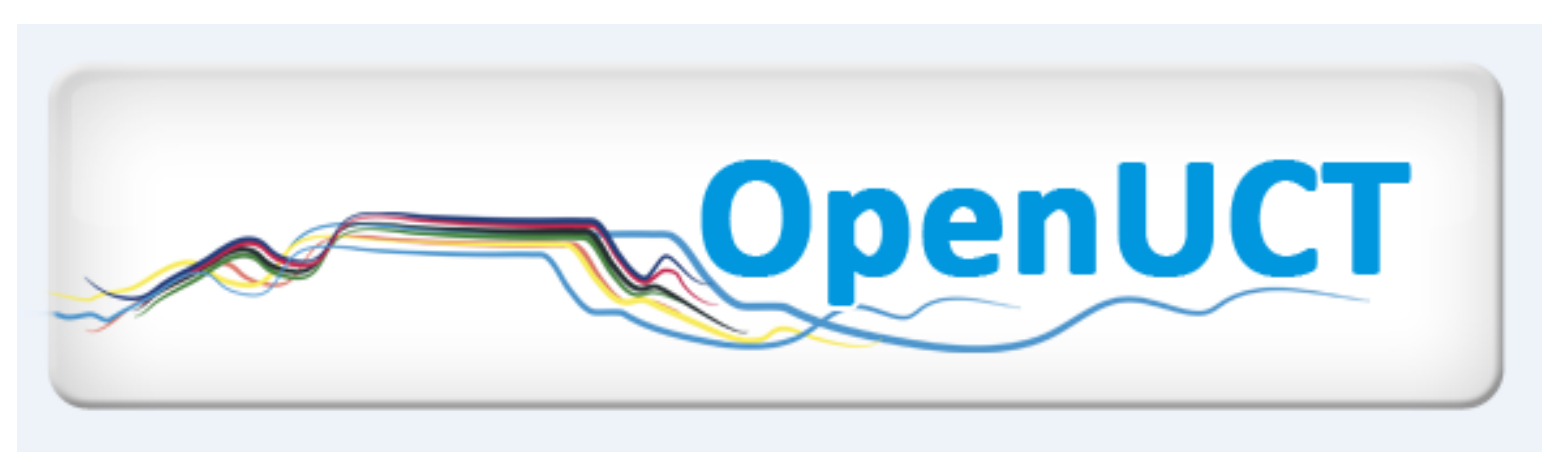

This is the author-approved manuscript version of a journal article published in:

Hodgkinson-Williams, C., Slay, H. \& Sieborger, I. 2008. Developing communities of practice within and outside higher education institutions. British Journal of Educational Technology. 39(3): 433-442. DOI: 10.1111/j.1467-8535.2008.00841.x.

It is made available under the terms of agreement between the author and the journal, and in accordance with the University of Cape Town's Open Access Policy for the purposes of research, teaching and private study.

http://www.openuct.uct.ac.za/sites/default/files/UCTOpenAccessPolicy.pdf 


\title{
Developing communities of practice within and outside higher education institutions
}

\author{
Cheryl Hodgkinson-Williams, Hannah Slay and Ingrid Siebörger
}

Cheryl Hodgkinson-Williams is an honorary research associate at the Centre for Higher Education Development at University of Cape Town. Hannah Slay is a lecturer in Computer Science, specialising in Human Computer Interaction, at Rhodes University. Ingrid Siebörger is a PhD student and a researcher in Computer Science, specialising in Information and Communication Technologies for Education, at Rhodes University. Address for correspondence: Hannah Slay, Hamilton Building, Computer Science Department, Rhodes University, Grahamstown, South Africa 6139. Tel: +27 46603 8640; email: h.slav@ru.ac.za

\begin{abstract}
Higher education institutions (HEls) are largely built on the assumption that learning is an individual process best encouraged by explicit teaching that is, on the whole, separated from social engagement with those outside the university community. This perspective has been theoretically challenged by those who argue for a social constructivist learning theory and a more collaborative approach to learning. Information and communication technologies (ICTs) afford lecturers and students an opportunity for extending the boundaries of a learning experience, not merely beyond the lone individual, but beyond the limits of discipline boundaries within a specific university community and beyond the institution into the local community. This paper illustrates how a collaborative effort between lecturers and students from the Computer Science and Education Departments at Rhodes University, teachers from the local community, the provincial Department of Education and a non-governmental organisation developed into an unfolding virtual and physical community of practice which enabled ICT take-up in a number of schools in the Grahamstown District, South Africa. This discussion of what has become known as the e-Yethu project provides an example of how ICTs, underpinned by the insights of social constructivism, the notion of 'community of practice' and in particular Hoadley and Kilner's C4P Framework for Communities of Practice, can serve to help HEls understand ways in which ICTs can provide opportunities for developing collaborative learning within HEls, and between the $\mathrm{HEI}$ and the local community.
\end{abstract}




\section{Introduction}

Higher education institutions (HEls) are operating in what Hernes (2006, p. 2) refers to as an era of paradoxes in which they face a range of economic, technological and political benefits and drawbacks. Middlehurst (2001, p. 4) categorises the drivers of change that present challenges to HEls globally into four broad categories, namely 'economic and business dynamics; social and intellectual developments; technological developments; and changes in government policy'. HEls worldwide, including South African universities, need to respond creatively to these challenges.

Economic challenges include global widening of inequalities despite some areas of rapid economic growth (Hernes, 2006, p. 2). Globally, governments are reducing funding (UNESCO, 2006) to HEls, yet expect lecturers to engage with a greater number and wider diversity of students, and provide them with the knowledge, skills and dispositions that are deemed necessary for society in the 21st century. In Africa, the economic constraints are particularly acute. Teferra and Altbach (2004) note that this may result in the serious shortage of published material, the lack of basic resources for teaching, the absence of simple laboratory equipment and supplies to undertake research and teaching, and in some countries, lengthy delays in salary payments. This situation is exacerbated by 'the constant decline of direct and indirect resources allocated for higher education by governments' (Teferra \& Altbach, 2004, p. 29). In South Africa, the economic constraints are manifest in the reduction of the government subsidy to HEls from $21.5 \%$ in 1991 to $13.9 \%$ in 2002-04 (UNESCO, 2006).

While technological developments are touted as a way of overcoming some of these economic constraints, the "benefits of technology are drastically skewed from one group and nation to another, as are the negative spillovers from many applications of technology' (Hernes, 2006, p. 2). Although new technologies have the potential to create more equal opportunities for people around the world (Thinyane, Slay, Terzoli \& Clayton, 2006), these same technologies 'can also generate new inequalities' (Hernes, 2006, p. 2). Czerniewicz (2004, p. 149) argues that as the global impact of digital communications expands, 'it is creating new realms of exclusion for students without access to computers'. Nonetheless, the affordances of ICTs (such as networking) provide a potential mechanism for a range of social and intellectual developments (Middlehurst, 2001).

Such developments include 'widening access and participation; rising public expectations of customer service, with a strong focus on individual choice and provider accountability; increasing emphasis on self-determination and self-help for individuals and groups; challenges to traditional notions of educational authority and forms of knowledge; and new patterns of interaction and relationship built on networks of all kinds' (Middlehurst, 2001, p. 7). Each of these brings challenges to higher education, perhaps none more fundamental than the challenge to 'traditional notions of educational authority and forms of knowledge'. Barnett (2000, p. 410), drawing on Gibbons, argues that 'the forms of knowledge that the university has prized are being challenged by new forms of knowledge valued in the wider world ... The new forms of knowledge, 
in contrast, are performative knowledges: now, what are held to be valid ways of coming into a relationship with the world are forms of action and engagement with and in the world (Gibbons et al, 1994)'. More pragmatically, Middlehurst (2001, p. 8) maintains that students or 'new "earner-learners" ...', are increasingly interested in the practical 'relevance' of higher education to the world of work. This epistemological perspective is also evidenced in the political challenges arising from the growing requirements by the government for both research and teaching at HEls to respond more directly to the needs of society. This in turn has led to growing government scrutiny (Barnett, 2000) or regulation (King, 2004) of HEls.

Although these challenges appear to undermine the lecturers' traditional authority, they have the benefits of acknowledging the 'authority of the practitioner and the student as co-contributors to the learning experience' (Middlehurst, 2001, p. 8). As Sayer (1992, p. 14) argues, "knowledge concerns not only "what is the case" or "knowing-that" but "know-how", that is, knowing how to do something, whether it be physical behaviour or communicating successfully with someone'.

By contrast, higher education has operated on the assumption that learning is an individual process best encouraged by explicit teaching that is, on the whole, separated from social engagement with those outside the university community. This perspective has been theoretically challenged by those who argue for a more collaborative socialconstructivist approach to learning, such as Wenger's (2004, p. 5) social theory of learning conceptual framework. This framework underpins Lave and Wenger's (1991) notion of 'communities of practice' defined by Wenger (2004) as 'groups of people who share a concern or a passion for something they do and learn how to do it better as they interact regularly'. This definition provides a way of conceptualising how students from $\mathrm{HEls}$ can engage in social participation as a process of learning and knowing. So understood, learning does not happen in a void, but occurs within a social environment which not only brings with it the history, traditions and 'wisdom' of the social environment or particular society, but also provides the student with a resource of other students, each with their own knowledge, experience and expertise, with whom to share ideas, negotiate meaning and work towards shared understandings. In this way, students 'act as partners in developing learning experiences and generating knowledge, and their collaborative construction of meaning is enhanced via different perspectives on shared experiences' (Dede, 2000, p. 281).

Lave and Wenger's and, subsequently, Wenger's concepts have been used in order to understand how people learn in various institutions and workplaces. Their concepts have been used to understand how trainee teachers can learn from more experienced teachers (Bathmaker \& Avis, 2005; Drever \& Cope, 1999), and how people in the workplace are able to learn from their colleagues through the establishment of communities of practice (Brown \& Duguid, 1991; Kimble, Hildreth \& Wright, 2001). Furthermore, their theories have been used to understand how intercultural learning arose out of collaborative European Union research projects (Somekh \& Pearson, 2002) and 
how PhD students found emotional and academic support through a collaborative peer community (Janson, Howard \& Schoenberger-Orgad, 2004).

Cousin and Deepwell (2005) make a strong case for using the concept of communities of practice to understand networked or virtual learning. Burbules and Callister (2000) argue that ICTs afford lecturers and students the opportunity for extending the boundaries of a learning experience not merely beyond the lone individual, but beyond the limits of lecture halls and even the specific university community through engagement across distance and social spaces. Hoadley and Kilner (2005, p. 37) note two examples in which ICTs enabled learning communities to function, and reflect that 'it is difficult to imagine the activities that took place in these communities happening via letters, books and face-to-face conversation-the distances are too great, the content evolves too quickly'. They developed a model of how learning takes place in knowledge-building communities. This C4P framework (Hoadley \& Kilner, 2005, p. 33) 'posits that knowledge is generated and shared when there is purposeful conversation around content in context. C4P is shorthand for content, conversation, connections, (information) context and purpose' (Figure 1).

While their framework was developed for online communities, these elements seem to be present in communities of practice that are partially online and offline. This paper endeavours to illustrate how one collaborative effort by lecturers and students from the Computer Science and Education Departments at Rhodes University with teachers from the local community, the provincial Department of Education and a non-governmental organisation combined in a naturally unfolding online and offline community of practice to enable ICT take-up in schools in the Grahamstown District, South Africa. This discussion of what has become known as the e-Yethu project provides an example of how ICTs, underpinned by the insights of social constructivism, the notion of 'community of practice' and in particular Hoadley and Kilner's (2005) C4P Framework for Communities of Practice, can serve to help HEls understand the extent to which ICTs can provide opportunities for developing collaborative learning between HEls and the local community.

\section{C4P Framework for Communities of Practice}

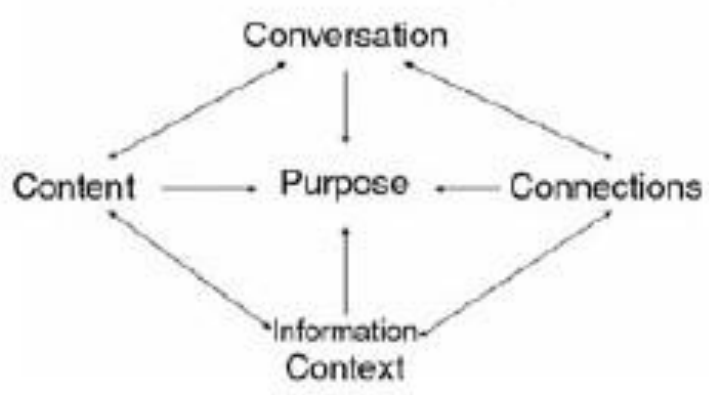

Figure 1: Hoadley and Kilner's (2005, p. 34) C4P Framework for Communities of Practice 


\section{Origins of the e-Yethu project}

This project originated as an informal joint venture between the Departments of Computer Science and Education of Rhodes University, located in Grahamstown, Eastern Cape. The Eastern Cape is one of the poorer provinces in South Africa, with 6300 schools, of which only $8.8 \%$ have ICT facilities and only $4.5 \%$ are being used for teaching and learning (Department of Education, 2004). The city of Grahamstown has a population of approximately 100000 people, of which approximately $40 \%$ are unemployed. Reflecting an old apartheid divide, the more affluent section of the population reside in what is called Grahamstown West, while the poorer and generally black population reside in Grahamstown East.

In 1998, Nathaniel Nyaluza Secondary School approached the Telkom Centre of Excellence (CoE) (housed in the Computer Science Department at Rhodes University) to sponsor Internet connectivity. The Telkom CoE was able to provide connectivity and a measure of technical support to a further three schools from Grahamstown East: Nombulelo Senior Secondary School was connected in 1999; Good Shepherd Primary School in 2001; and George Dickerson Primary School in 2003.

Independently, the Education Department at Rhodes started supporting Nathaniel Nyaluza Secondary School in 1998 with pedagogical strategies for integrating ICTs into the curriculum. Realising their mutual dependence, the two staff members from the CoE and the Education Department decided to become 'partners' in providing support for the schools computer laboratories, Internet connections and educational advice for maximising the use of ICTs for teaching and learning.

This informal partnership was formalised in 2004 when the staff member from the Education Department secured a research grant from the South African National Research Foundation to investigate 'What educators and learners in the secondary schools in Grahamstown perceive as the benefits and drawbacks of integrating ICT into the curriculum'. The research team include the two lecturers mentioned earlier, two Master of Education students and one Master of Science student. After the presentation of the MSc students' proposal, several other Computer Science and Education postgraduate students expressed an interest in participating in the support of ICTs in the local school community. As part of the field trips to the schools for the research project, participant teachers were invited to meet informally with the researchers and the other students once a week. Eventually, in 2005, this group constituted itself more formally under the name 'e-Yethu'. e-Yethu means 'ours' in isiXhosa and the name was chosen to reflect how the project is driven by this growing community. To facilitate collaboration, the face-to-face meetings were extended to the use of a mailing list and a wiki to which all members of e-Yethu group had editing rights.

The establishment of the wiki prompted deliberation of the aims of this group. After some discussion, both offline and online, the aims of e-Yethu that emerged were to support local schools as much as possible by: 
- aiding schools in sourcing computer and other ICT equipment;

- supporting schools technically while providing transfer of technical skills to teachers and learners;

- facilitating collaboration amongst schools; and

- providing ICT literacy training for teachers and learners.

In addition to these community outreach-type aims, it was made clear that e-Yethu was also committed to traditional 'academic' aims and would strive to provide research output in the following areas:

- cost-effective broadband network solutions for schools;

- sustainable ICT infrastructure for schools; and

- ICT integration across curriculum.

As a way of understanding the relationship between the participants in the e-Yethu Schools project and how this growing Community of Practice built and shared knowledge and skill, we used Hoadley and Kilner's (2005) C4P Framework for Communities of Practice as a conceptual framework.

\section{Discussion}

To frame our discussion, we used Hoadley and Kilner's five key elements: purpose, content, conversations, connections and context. In order to illustrate the extent to which ICTs can provide opportunities for developing collaborative learning between HEIs and the local community, we will refer to e-Yethu's relationship with two Grahamstown East schools, Mary Waters Secondary School and C. M. Vellem Primary School.

\section{Purpose}

Hoadley and Kilner (2005) variously refer to the importance of having a clear purpose as it 'is the reason for which the members come together in the community' (p. 33); 'creates energy and produces results' (p. 34); and 'provides the meta-connection between all the other elements' (p. 33), without which 'knowledge building will founder' (p. 33). In relation to e-Yethu, there are at least three distinguishable 'threads' of purpose that can be untangled. The first, as is evident in the stated 'aims' earlier, is the student researchers and the other students' community engagement purpose as evident in 'agent' implicit in three of the aims-'aiding schools', 'supporting schools technically' and 'providing training'. The second purpose is quite explicitly the academic research purpose of producing 'research output', shared by the staff and student researchers. A third, somewhat implied purpose is the collaboration among schools, which may at face value seem to represent the community purpose, but it is still mediated through the student researchers 'facilitating' the process. On reflection, then, it would seem that despite the opportunity to edit the aims on the wiki, the teachers did not create a more specific purpose for themselves, but merely endorsed the version of the aims drafted by the student researchers.

However, these shared purposes certainly brought together the fairly ad hoc and disjointed support offered by the two departments within the HEI, enabled them to provide 
a much more coordinated and ultimately more successfully support to the local schools and created a stable focus despite the constantly changing student body that often bedevils HEl student engagement projects. As the purpose was therefore clearly biased towards the staff and students, the knowledge building was probably biased towards the HEl.

\section{Content}

According to Hoadley and Kilner (2005, p. 33), content refers to 'explicit, static knowledge objects' and involves 'one-way communication of information'. They further explain that content serves four purposes: 'it attracts members by providing immediate value; it socializes new members by implicitly communicating what kinds of topics and voices are appropriate; it serves as a basis for conversation; and it motivates members as they see themselves jointly building their domain of knowledge' (Hoadley \& Kilner, 2005, p. 34).

Key knowledge built during the first year of HEl community engagement projects has become often 'lost' to the students engaged in similar activities in subsequent years. In the e-Yethu Project, the wiki provided the shared space in which this content was captured and refined, providing a record that could be accessed by the school and new student technicians. The wiki became the 'hold-all' of basic information such as the location of and directions to the schools; the 'champion' teachers and their contact details; and inventory of their hardware, software and connectivity infrastructure and notes to information technology technicians. It also itemised each visit by a student and/or lecturer, so that there was a history of the activities undertaken to maximise the immediate value of each engagement.

While this technical and organisational 'knowledge' was of more particular interest to the staff and students from the $\mathrm{HEl}$, the wiki also provided the names of the staff and students that the teachers could approach for help. This kind of information is very difficult for schools to determine as the student cohort is not the same from one year to the next. In addition, the wiki linked to educational websites reported on the progress of the project and provided access to conference papers that involved the project. However, most of these sites were suggested by the students and not the teachers, indicating a possible uneven power relationship in terms of whose choices of documents and websites were deemed the most valuable.

Perhaps the most important content-related item on the wiki was the to-do list that itemised the list of activities, list of people responsible and the anticipated dates of completion. This 'checklist' of activities really helped keep the group focused, motivated and accountable as an explanation of progress was required each time the group met. Although it would appear that the students' ideas really shaped the wiki and that the consequent knowledge building was biased towards the HEI, access to this knowledge by teachers in the community was made possible in a transparent way not undertaken before. Schools were able to keep track of activities and were able to make contact with specific people in the project who could support them with particular expertise. So, 
although the power differential still favoured the HEI, the overt to-do list opened up a space for debate around these activities, where previously the schools would have been mere recipients of the goodwill of the HEl staff and students.

In the beginning of 2005, Mary Waters approached the Shuttleworth Foundation for a tuXlab (refurbished computers that run as thin clients off a server). As a requirement for the provision of the tuXlab, Mary Waters needed to secure ICT technical and educational support, and approached the e-Yethu project for such support. In May 2005, Mary Waters was awarded a tuXlab from the Shuttleworth Foundation, which together with e-Yethu project members and pupils from Mary Waters, installed the computer lab. Shortly after this, the e-Yethu project installed an Internet connection with WiFi technologies to the school. Later that same year, an application from this school to Dell for a donation of new computers was successful and the school received 20 additional Pentium 4 Dell computers. Again, the e-Yethu team was contacted for the setup and installation of a second computer lab, as well as the extension of the school's local area network (LAN). Since then, e-Yethu has been supporting Mary Waters both technically and pedagogically with regard to their ICT infrastructure. The school's ICT infrastructure would not have been possible without the collaborative efforts of the broader community, including the e-Yethu team, together with the Shuttleworth Foundation, Dell and the Telkom CoE.

During the course of 2006, C. M. Vellem received a donation of second-hand computers from one of the local independent (private) schools. C. M. Vellem approached e-Yethu for networking within the computer lab, possible hardware and software support, as well as an Internet connection. With the aid of the Telkom CoE, e-Yethu was able to provide the school with an Internet connection using WiMAX technologies, as well as the necessary equipment to build a LAN. In 2007, the e-Yethu team managed to secure a donation of thin client computers from the tuXlab project (now run by Inkululeko Technologies) and a server from the Eastern Cape Department of Education through the Imbewu project for C. M. Vellem. Imbewu, meaning 'seed' in isiXhosa, is an educational transformation project within the Eastern Cape Department of Education that was intended to plant seeds of education transformation and renewal within the province.

As well as the tangible benefit to the schools, this relationship has also developed skills within the local community, and among the postgraduate students at Rhodes University. While it may not be obvious that learning was the goal of the community of practice, it 'was simply a way in which the participants in this community adapted to life in the group' (Hoadley \& Kilner, 2005, p. 32).

\section{Conversation}

Conversation is defined as an information exchange between two or more parties and can be performed in person or via ICTs (Hoadley \& Kilner, 2005). In the e-Yethu project, conversation is facilitated via face-to-face weekly meetings and a team mailing list. The regular meetings have proved to be the 'glue that binds' this group together. They help to build relationships amongst members which can be challenging to achieve in a 
purely virtual environment. Such relationships are vital as 'a strong personal relationship was felt to be essential to carry the community through the periods of e-media communication' (Kimble et al, 2001, p. 230). The moderated mailing list enables the group to keep in contact in between face-to-face meetings. It facilitates highlighting of organisational needs within the project, mentoring new members, supporting members, participation in collaborative projects and keeping people up to date on various aspects of the project.

As Hoadley and Kilner (2005, p. 33) note, when conversation is missing, 'knowledge may transfer but is unlikely to be generated'. Conversation facilitates the new idea generation that provides momentum for the group's activities.

\section{Connections}

Closely related to conversation is the notion of a connection. Hoadley and Kilner (2005, p. 33) define connections as interpersonal contacts between members of the community, and describe this relationship saying, 'Connections spark conversations and add context to content.' If connections are missing, 'there will be fewer contributions of content and conversation, and the contributions will have less context' (Hoadley \& Kilner, 2005, p. 33). Within the e-Yethu project, when it has been difficult for all parties to meet regularly, we have found that with less conversation, less content is generated. This in turn slows down the momentum of the project. Similar effects are also experienced when the mailing list is underused.

\section{Context}

Hoadley and Kilner (2005, p. 33) define context as the 'who, what, where, when, why and how that enables community members to assess whether and how information is relevant to them'. Context provides the necessary information to team members in order to build and extend existing knowledge generated by the e-Yethu group. Context is derived from the group wiki, the archived mailing list and the regular meetings. In the wiki, every school visit is documented and serves to inform team members for subsequent visits. Conversations started in face-to-face meetings are often continued on the mailing list, which in turn acts as a means of archiving ideas that can be built upon at a later stage. In addition, the mailing list is used to coordinate current activities.

When team members failed to update the wiki with current information, subsequent activities were negatively affected because of lack of understanding on the part of other team members. This illustrated Hoadley and Kilner's (2005, p. 33) contention that if awareness of context is missing, "the community is prone to misinterpret content or apply knowledge inappropriately to new situations'.

\section{Conclusion}

While there is still much to be achieved, the establishment of the e-Yethu Project appears to have provided a sufficiently stable community of practice to take the project vision forward. If HEls were able to encompass a view of learning as a 'fundamentally social phenomenon' (Wenger, 2004, p. 3), this may facilitate the potential of working in 
collaborative groups through the exploitation of the affordances that ICTs offer in supporting learning within the university and in cooperation with the community.

\section{References}

Barnett, R. (2000). University knowledge in an age of complexity. Higher Education, 40, 409422.

Bathmaker, A.-M. \& Avis, J. (2005). Becoming a lecturer in further education in England: the construction of professional identity and the role of communities of practice. Journal of Education for Teaching, 31, 1, 47-62.

Brown, J. S. \& Duguid, P. (1991). Organisational learning and communities-of-practice: toward a unified view of working, learning and innovation. Organisation Science, 2, 1, 40-57.

Burbules, N. C. \& Callister, T. A. (2000). Universities in transition: the promise and the challenge of new technologies. Teachers College Record, 102, 2, 271-293.

Cousin, G. \& Deepwell, F. (2005). Designs for network learning: a communities of practice perspective. Studies in Higher Education, 30, 1, 57-66.

Czerniewicz, L. (2004). Cape of Storms or Cape of Good Hope? Educational technology in a changing environment. British Journal of Educational Technology, 35, 2, 145-158.

Dede, C. (2000). Emerging influences of information technology on school curriculum. Journal of Curriculum Studies, 32, 2, 281-303.

Department of Education (2004). White paper on e-Education: transforming learning and teaching through information and communication technologies. Pretoria, South Africa: Department of Education.

Drever, E. \& Cope, P. (1999). Students' use of theory in an initial teacher education programme. Journal of Education for Teaching, 25, 2, 97-109.

Hernes, G. (2006). The new century: societal paradoxes and major trends. In S. D'Antoni (Ed.), The virtual university: models and messages, lessons from case studies (pp. 1-11). Paris: UNESCO.

Hoadley, C. M. \& Kilner, P. G. (2005). Using technology to transform communities of practice into knowledge-building communities. SIGGROUP Bulletin, 25, 1, 31-40.

Janson, A., Howard, L. \& Schoenberger-Orgad, M. (2004). The odyssey of PhD students becoming a community of practice. Business Communication Quarterly, 67, 2, 168-181.

Kimble, C., Hildreth, P. \& Wright, P. (2001). Communities of practice: going virtual. In Y. Malhotra (Ed.), Knowledge management and business model innovation (pp. 220-234). Hershey, Medford, NJ and London: Idea Group Publishing.

King, R. (2004). The university and the regulatory state. In R. King (Ed.), The university in the global age. Basingstoke, Hampshire: Palgrave Macmillan.

Lave, J. \& Wenger, E. (1991). Situated learning: legitimate peripheral learning. Cambridge: University of Cambridge Press.

Middlehurst, R. (2001). University challenges: borderless higher education, today and tomorrow. Minerva, 39, 3-16.

Sayer, A. (1992). Method in social science: a realist approach (2nd Ed.). London: Routledge.

Somekh, B. \& Pearson, M. (2002). Intercultural learning arising from pan-European collaboration: a community of practice with a 'hole in the middle'. British Educational Research Journal, $28,4,485-502$.

Teferra, D. \& Altbach, P. G. (2004). African higher education: challenges for the 21 st century. Higher Education, 47, 1, 21-51.

Thinyane, M., Slay, H., Terzoli, A. \& Clayton, P. (2006). A preliminary investigation into the implementation of ICTs in marginalized communities. Southern African Telecommunication Networks and Applications Conference (SATNAC) 2006.

UNESCO (2006). Commitment to education: public spending. In Human Development Report 2006. Beyond scarcity: Power, poverty and the global water crisis. Accessed December 10, 2007 from http://hdr.undp.org/en/reports/global/hdr2006/

Wenger, E. (2004). Communities of practice: a brief introduction. Accessed December 10, 2007, from http://www.ewenger.com/theory/communities_of_practice_intro_WRD.doc 